\title{
Taboo Words Used in the Hollywood Movie Walk of Shame
}

\author{
Putu Sintha Handayani $^{1^{*}}$, Ni Luh Putu Krisnawati ${ }^{2}$ \\ ${ }^{[12]}$ English Department, Faculty of Arts, Udayana University \\ ['[handayanisintha@gmail.com],2[inacrisna@gmail.com] \\ *Corresponding Author
}

\begin{abstract}
Another way to express feeling, relief from burden or show how intimate someone with another is by using taboo words; even though, it is a forbidden language. However, the using of taboo words can induce misunderstanding if it is used in inappropriate situation. Moreover, there are many taboo words used by characters in the Hollywood movies which can be imitated by people from other countries without knowing the proper meaning and situation to use them because in some context, some of taboo words can have another meaning and what is not taboo for someone may be taboo for others. Seeing this phenomenon, the aims of this study are to classify types and find the functions of taboo words. The data source is one of the Hollywood movies entitled Walk of Shame. Therefore, people can be more aware to use taboo words. Some methods and techniques were applied for this research. In collecting data, content-analysis method and observation and note taking techniques were used. The following step was analysing the collected data. Qualitative method was used and the analysis techniques were collecting, reducing and classifying. The method in presenting the result is descriptive method; the result of the analysis is presented and explained in details by using words and sentences. The Theory proposed by Jay (1992) is combined with the theory proposed by Halliday and Hasan (1985); those are used to classify types of taboo words. Moreover, the theory proposed by Liedlich (1975) is used to find the function of using it. Six of ten types of taboo words were found; they are cursing, profanity, slang, ephitets, vulgarity, as well as insult and slur. Moreover, there were six functions of using taboo words found, they are creating attention, discredit, endearment, creation of strong interpersonal identification, provoking violent confrontation, and providing catharsis.
\end{abstract}

Key words: Taboo, words, context, functions.

\begin{abstract}
Abstrak
Cara lain untuk mengekspresikan perasaan, meringankan beban atau menunjukan seberapa dekat seseorang dengan yang lainnya adalah dengan menggunakan kata-kata tabu, walaupun itu merupakan bahasa yang dilarang. Namun, penggunaan kata-kata tabu dapat menimbulkan kesalahpahaman apabila digunakan dalam situasi yang tidak sesuai. Terlebih lagi, terdapat banyak kata tabu yang digunakan oleh para pemain film di dalam film Hollywood yang dapat ditiru oleh orang-orang dari negara lain tanpa mengetahui arti dan situasi yang sebenarnya karena dibeberapa situasi, beberapa kata-kata tabu dapat memiliki makna yang berbeda dan apa yang dianggap tabu oleh seseorang kemungkinan tidaklah tabu untuk orang lain. Mengetahui kejadian ini, tujuan dari penelitian ini adalah untuk mengklasifikasikan tipe dan fungsi saat menggunakan kata-kata tabu. Sumber data berasal dari salah satu film Hollywood yang berjudul Walk of Shame. Sehingga, orang-orang akan menjadi lebih berhati-hati dalam
\end{abstract}


menggunaan kata-kata tabu. Beberapa metode dan teknik diaplikasikan dalam penelitian ini. Metode konten analisis digunakan sebagai metode dalam mengumpulkan data dan teknik dalam mengumpulkan data adalah observasi dan pencatatan. Langkah selanjutnya adalah menganalisis data yang sudah dikumpulkan. Metode kualitatif digunakan dalam menganalisis data dan teknik menganalisis yang digunakan adalah mengumpulkan, mengurangkan, dan menggolongkan. Metode deskriptif digunakan untuk menyajikan hasil analisis; hasil analisis disajikan dan dijelaskan secara rinci menggunakan kata-kata dan kalimat-kalimat. Teori yang diajukan oleh Jay (1992) dikombinasikan dengan teori yang diajukan oleh Halliday dan Hasan (1985) digunakan untuk menggolongkan tipe kata-kata tabu. Ditambah lagi, teori yang diajukan oleh Liedlich (1975) digunakan untuk menemukan fungsi penggunakan kata-kata tabu. Enam dari sepuluh tipe kata-kata tabu ditemukan; keenam tipe itu adalah cursing, profanity, slang, ephitets, vulgarity, begitu juga dengan insult dan slur. Ditambah lagi, enam fungsi dari menggunakan kata-kata tabu ditemukan, keenam fungsi itu adalah creating attention, discredit, endearment, creation of strong interpersonal identification, provoking violent confrontation, dan providing catharsis.

Kata kunci: Tabu, kata-kata, konteks, fungsi-fungsi.

\section{Background of the Study}

Language is a device for human to communicate with one another. By using language people interact and express their feeling through words they utter. The way people express their feelings are different from each other as well as its usage. Moreover, there are some expressions of people such as anger, frustration, even happiness and forbidden language or taboo words chosen to express them, which might induce misunderstanding. Even, the impact of using this forbidden language in spoken is worse than in writing. Allan and Burridge (2006 : 245) states that "...the sound of taboo words was found to be more disturbing than their appearance in print..."

However, people have their reasons why they are using taboo words with one another. One of the reasons is that an emotional expression of people to the others. Jay (2000:81) states that "cursing is an emotional element of language that alters the way we view ourselves and others."

Beside as the way to express their feelings, taboo words are also used by a group of people in a community as a sign of the group members. People in group will not feel uncomfortable if they use taboo words with one another. However, people who are not in the group will feel uncomfortable. Context of situation takes its role in this case because in some situation what is taboo for someone, it might not be taboo for others. In the context of situation as well, the relationship between the speaker and the listener; as well as the condition the speaker utter the utterance can influence the meaning of one type of taboo words to become to another type or in some situation what is called as taboo is no longer taboo. It is necessary if those taboo words are classified; and also knowing the context of situation when people use taboo words are required to avoid misunderstanding.

This study applied three theories: first is the theory proposed by Jay (1992) for types of taboo words and theory proposed by Halliday and Hasan (1985) for the context of situation to classify type of taboo words and the last is the theory proposed by Liedlich (1973) for the functions of taboo words. The aims of this study are to classify types of taboo words and find what the functions of using taboo words uttered by the characters in the movie entitled Walk of Shame. It is necessary to get more knowledge of taboo words so people can 
be more aware when to use them in society and avoid misunderstanding.

\section{Problem of the Study}

a) What types of taboo words are used in the movie Walk of Shame?

b) What are the functions of taboo words used by the characters in the movie Walk of Shame?

\section{Aims of the Study}

a) To classify the types of taboo words used in the movie Walk of Shame.

b) To find out and describe the function of taboo words used by the characters in the movie Walk of Shame.

\section{Research Method}

There is a systematic way to conduct the research. These steps are used to produce a scientific writing. The methods are divided into four: data source, method and technique of collecting data, method and technique of analysing data, and method and technique of presenting analysis.

\subsection{Data Source}

The data of this study were taken from one of Hollywood movies entitled Walk of Shame. The genre of this movie is romantic comedy, stared by Elizabeth Banks and directed by Steven Brill. The movie was released in 2014 in the United Stated by Focus Features. The reason why this movie was chosen was that it contains lots of taboo words used by the characters in this movie. Some of taboo words used change to other types and the context of situation when the characters utter the utterance influencing this phenomenon.

\subsection{Method and Technique of Collecting Data}

In collecting data of this research, content-analysis method was used and the techniques of collecting the data were as follows: First, watching the movie several times to understand the story. Second, the English subtitle was downloaded from the internet. Third, by using the English subtitle, the taboo words found in the movie were collected by writing down.

\subsection{Method and Technique of Analysing Data \\ Qualitative method was used as the} method of analysing data. The techniques of analysing data were as follows: First, using the English subtitle obtained from the internet; the taboo words used by the characters in the movie Walk of Shame were collected by taking a note. Second, after collecting all of the taboo words, the collected data were reduced. Third, after reducing the data, the types of taboo words were categorized and analysed.

\subsection{Method and Technique of Presenting Analysis}

The method of presenting the analysis is descriptive method. The technique in presenting the result of the analysis is presented and explained in details by using words and sentences.

\section{Result and Discussion}

The result and discussion of this research gives one sample data in each type of taboo word found in the movie Walk of Shame.

5.1 Cursing has a purpose to invoke or wish harm on another person through the use of certain words or phrases. Theoretically, word motherfucker is classified into obscenity, word that has obscene meaning. However, in this 
situation the meaning of word motherfucker is changing.

(1-1) "Motherfucker!" 00:41:52

Meghan is in crack house borrows the drug dealers' cell phone, Pookie, Hulk, and Scrilla. When Meghan is calling her ex-boyfriend; suddenly, a group of man come and shooting gun to them and one of them says, "Die slow, motherfucker!". The relation a group of man with the gun with Pookie and friends is stranger.

According to the situation in the dialogue when the word was uttered, motherfucker is defined as one that is formidable, contemptible, or offensive usually used as a generalized term of abuse (Online Merriam Webster). Seeing the context of situation, a group of man shot Pookie and friends and the word motherfucker was used by them to offend and abuse Pookie and friends by insulting their names to show how much they hate Pookie and friends. Those strangers are Pookie's and friends' rival in selling drugs.

The function of using this taboo word is provoking violent confrontation. Those strangers get envious because Pookie's and friends can sell many drugs and have many customers. Therefore, those strangers do violent confrontation by uttering taboo word as well as shooting Pookie's and friends caused by their psychological needs.

5.2 Profanity is taboo word that does not denigrate to God. The speakers used the sacred word in general situation or not in the religious situation.

\section{(1-2) “God" 01:20:33}

Gordon, Denise, and Rose are going to the tow car because the G.P.S of keytactive shows them if Meghan is right there. Finally, they find Meghan stuck in her car when she forced to get her car out from there because the guard there does not allow Meghan to take her car without the car ownership certificate. Meghan leaves her car and goes inside Rose's car. They rejoice because they, finally, can find Meghan after almost all day searching. Rose is so happy, she can not believe if they can find Meghan alive.

The word God used by the character does not denigrate to God and in their journey while they are searching Meghan, they never talk about something religious or went to the church before. The character used or uttered the word God to show her unbelievable feeling, how relieved and happy she is after finding her friend in good condition because she thinks her friend is suffering somewhere.

The function of using the word God is providing catharsis. She shows her happy feeling after finding Meghan safe and releases all of her feeling of anxiety.

5.3 Vulgarity is neither obscenity nor taboo. Taboo words classified as vulgarity shows the crudeness of the street language.

\section{(1-3) "Ass" 00:51:54}

Meghan sells the crack which has been given by Pookie to get some money. When she sells it to a man in the park, who she saw are selling a crack to some people too, and tells him if she gets the crack from Scrilla, he gets angry. It because Scrilla and friends is his rival in selling crack; therefore, he refuses firmly and tells his friends to catch Meghan. Meghan dodges from their pursuit by going into the bus. The bus driver tells her the price she must pay for the ride. However, Meghan has no money and she tries her best to change the subject and explains what happened to her actually, because in the bus, the whole people, including the bus driver, think that she is a prostitute woman who tries to get ride 
for free. Then, the bus driver gives her some advices and the advice end with the payment or she have to get her ass off the bus. The relationship between Meghan and the bus driver is stranger. That is the first time they meet.

The word ass means a person's buttocks or anus (Online Oxford Dictionary). The word ass used by the character in the movie is neither taboo nor obscenity. When the character uttered the word ass, the bus driver feels a little annoyed and she uttered that word while giving advice to another character because she cannot pay. She did not have purpose to offend another character, she uttered it as if it was a common language used in daily because she uttered it in front of the old people in the bus casually.

The function of using the word ass is discredit. The bus driver feels dissatisfied with what Meghan has done. If she wanted to use public transportation then she should pay like other passengers.

5.4 Slang is vocabulary developed in certain community for ease of communication and it is used as the group's identity.

\section{(1-4) "Asshole" 01:07:39}

Theoretically, word asshole is classified as insult and slur; to give a verbal attack to someone. However, the situation when it was uttered makes the function and the type change.

The police helps the kid find his bike stolen by Meghan. At the same time, Meghan is the fugitive that the police are trying to catch as well. On the way to find Meghan and the kid's bike, the kid is whining and giving command disrespectfully to the police officers. It makes one of the police officers lose his temper and shout back to the kid. Then, the kid cannot say anything and cry. Another police (Dave) blames his friend
(Walter) for shouting back the kid and hurting the kid's feeling. Walter thinks that it was not his fault; it is because the kid is an asshole. He just finishes what has been started by the kid. The relationship between the police and the kid is stranger. The police are doing their job to help people when they need help.

The word asshole means the opening between a person's buttocks through which solid waste passes from the body (Online Merriam Webster). In this situation, the word asshole has different meaning; it is a slang word that means someone who is stupid, incompetent or detestable (Online Merriam Webster). The police (Walter) is not in condition talking about something which is related with human body's part; he says asshole about the kid to his friend right after arguing with the kid because the kid makes him get upset.

The function of using word asshole is providing catharsis. The speaker releases his feeling of upset because the kid's bad attitude. However, the speaker does not utter the word asshole to the kid directly. The speaker says it to his friend as an argument or his opinion about the kid.

5.5 Ephitets is an emotional language uttered from frustration.

\section{(1-5) "Fuck" 00:32:04}

Theoretically, the word fuck is classified into obscenity which has vulgar meaning. However, the word fuck has different meaning in the situation.

Rose, Meghan's best friend, gets up in the morning in her house. She is calling Meghan to make sure if she gets home safely while going to the kitchen for drink. However, she does not realize yet if Meghan is not home yet. Suddenly, there is an old man sitting in her dining room. She gets shocked because she thinks that she spent all her night with very young cute boy. The old man said 
that if it must be his son and it means she took a wrong person to her house at that night when she drunk.

The word fuck means having sexual intercourse with someone (Online Oxford Dictionary) and will be more appropriate if it is classified into obscenity. However, in this situation, the speaker does not want to have sexual intercourse with someone. Rose uttered the word fuck is to show her emotion of anger and frustration because she takes a wrong person to her house and spends all night with him. There is another definition of the word fuck as well; fuck is exclamation used alone or as a noun or verb in various phrases to express annoyance, contempt, or impatience (Online Oxford Dictionary). The word fuck functions to provide catharsis. The speaker uttered the word fuck to express and relieve her feeling of anger and frustration.

5.6 Insult and slurs are verbal attacks on other people and the words are meant to harm the listener or the target by denoting the target's characteristic.

\section{(1-6) "Son of a bitch" 01:01:47}

Rose and Denise come to Gordon's apartment to ask for an explanation about what happened with him and Meghan because they do not know where Meghan is and she left her phone in Gordon's apartment. Denise misunderstands and concludes that Gordon has killed Meghan. The relationship between Rose, Denise, and Gordon was stranger after Rose and Denise listen to his explanation carefully and look for Meghan together.

Son of a bitch is an unpleasant man (Online Cambridge English Dictionary). It means a nasty or rude man. In the movie, one of the characters uttered this dialogue because she misunderstands and thinks that her friend has been killed and she gets angry. Denise calls him as son of a bitch to give him a verbal attack followed by physical attack. They do not know each other; however, the taboo word used in this situation is appropriate because Denise gets angry because she thinks her best friend has been killed.

The function of phrase son of a bitch is provoking violent confrontation. The speaker is worried about her friend, Meghan. When she misunderstands and thinks that Gordon has killed her friend, she calls him as son of a bitch to release her feeling of being angry with him caused by psychological needs. Moreover, the verbal attack is followed by physical attack as well to hurt him.

\section{Conclusion}

There are six of ten types of taboo words found the Hollywood movie entitled Walk of Shame. They are cursing, profanity, slang, ephitets, vulgarity as well as insult and slur. Moreover, there are six functions of using taboo words found as well. They are creating attention, discreadit, endearment, creation of strong interpersonal identification, provoking violent confrontation, and providing catharsis.

The topic, the participant, in what situation taboo word is used, the reason the taboo word is used, when and to whom the word is uttered affect the change in the type, the meaning and the function of taboo words such as the word asshole which changes from insult into slang, the meaning of the word asshole is still the same; however, the type and function of the word changes because the reason of the word is used, and to whom the word is uttered. Another example is fuck which changes from obscenity into ephitets. The meaning, the type, and the function of the word fuck changes because of the topic, the situation when it is uttered, and the reason why it is used. 


\section{Bibliography}

Allan, K. and Burridge, K. (2006). Forbidden Words: Taboo and the Censoring of Language. Cambridge University Press, Cambridge.

Halliday, M.A.K and Hasan, R. (1985). Language, Context, and Text: Aspect of Language in a SocialSemiotic Perspective. Oxford University Press, Oxford.

Liedlich, R. (1973). Coming To Terms with Language: An Anthology. Wiley, New York.

n.d.Http://www.subscene.co.in/movies/w alk-of-shame-movie-subtitles2014.html [Accessed on October 13, 2016].

Jay, T. (1992). Cursing in America: A Psychological Study of Dirty Language in The Courts, in The Movies, in The Schoolyards and on The Streets. Jhon Benjamins Publishing Co., Philadelphia.

Jay, T. (2000). Why We Curse: A NeuroPsycho-Social Theory of Speech. Jhon Benjamins Publishing Co., Amsterdam, The Netherland.

Kothari, E.R. (2004). Research Methodology: Methods and Techniques. New Age International (P) Ltd. Publisher, New Delhi.

Singh, Y.K. and Bajpai, R.B. (2008). Research Methodology Techniques and Trend. APH Publishing Corporation, New Delhi.

Walk of Shame [internet]. n.d. Box Office. Available from: www.boxofficemojo.com/movies/? $\mathrm{id}=$ walkofshame.htm. [Accessed on April 14, 2017].

Watzlawik, Meike and Born, Aristi. (2007). Capturing Identity: Quantitative and Qualitative Methods. University Press of America Inc., Maryland.

Cambridge English Dictionary [internet]. Available http://dictonary.cambridge.org/dicti onary/english [accessed on December 4, 2017)

Merriam Webster [internet]. Available from: http://merriamwebster.com/dictionary [accessed on December 4, 2017]

Oxford Dictionary [internet]. Available from:

http://en.oxforddictionaries.com/de finition [accessed on December 5, 2017] 